\title{
Hibernacula of Myotis bats in artificial caves in the Leningrad Region
}

\author{
Dmitry N. Kovalyov
}

\begin{abstract}
Myotis bats were investigated from all known artificial caves of Leningrad Region. The bat's wintering places (hibernaculi) studied during eight seasons from 2007 to 2015 within a long-term bat monitoring effort. The following mouse-eared bat species were found: Myotis dasycneme (Boie, 1825) pond myotis, M. daubentonii (Kuhl, 1817) — Daubenton's myotis, M. nattereri (Kuhl, 1817) — Natterer's myotis, and species complex Myotis brandtii/mystacinus — Brandt's/whiskered myotis. Massive hibernacula of the Natterer's myotis, Brandt's/whiskered myotis, and pond myotis was found within group of Staroladozhskije Caves; namely, Tanechkina Cave at present is a biggest known simultaneously wintering of Myotis bats. Hibernaculi and theirs vicinity microclimatic conditions were described with using instrumental measurements of the temperature and humidity. The specific preferences of the studied species were identified that connected with position of hibernating groups relative cave entrances and underground water capacity, specific micro-conditions of temperature and humidity ranging. As result, we have a preliminary assessment of the relationship between the size of the hibernacula and the well-being of the mouse-eared bat populations from territory of Leningrad Region. In addition, we attempted to assessment of a vulnerability of the some hibernating colonies, and, in general, populations of the several studied species.

How to cite this article: Kovalyov D.N. 2017. Hibernacula of Myotis bats in artificial caves in the Leningrad Region // Russian J. Theriol. Vol.16. No.1. P.94-109. doi: 10.15298/rusjtheriol.16.1.09
\end{abstract}

KEY WORDS: Myotis, wintering, artificial cave, temperature, humidity, Russia.

Dmitry N. Kovalyov [dimakov@list.ru], Faculty of Biology of Saint-Petersburg State University, Universitetskaya nab. 7/9, Saint-Petersburg 199034, Russia.

\section{Зимовки ночниц в пещерах-штольнях Ленинградской области}

\section{Д. Н. Ковалев}

РЕЗЮМЕ. Исследованы ночницы Myotis из всех известных искусственных пещер Ленинградской области. Зимовки летучих мышей (hibernaculi) изучались в течение 8 сезонов с 2007 по 2015 г. в рамках долгосрочного мониторинга летучих мышей. Были обнаружены следующие виды ночниц: Myotis dasycneme (Boie, 1825) — прудовая ночница, M. daubentonii (Kuhl, 1817) — водяная ночница, M. nattereri (Kuhl, 1817) - ночница Наттерера, и видовой комплекс Myotis brandtii/mystacinus ночница Брандта/усатая ночница. Внутри группы Староладожских пещер обнаружена массовая зимующая колония ночницы Наттерера, прудовой ночницы и видов комплекса Брандта/усатая; а точнее Танечкина пещера в настоящее время является местом самого большого скопления одновременно зимующих летучих мышей Myotis. Описаны микроклиматические условия зимовок и их окрестностей с использованием инструментальных измерений температуры и влажности. Выявлены специфические предпочтения изученных видов, связанные с удаленностью зимующих групп относительных входов в пещеры и от подземных водоемов, специфических условий температуры и влажности. В результате мы получили предварительную оценку взаимосвязи между размером зимовок и благополучием популяций ночниц на территории Ленинградской области. Кроме того, мы попытались оценить уязвимость, как некоторых зимующих колони, так и популяций нескольких изученных видов в целом.

КЛЮЧЕВЫЕ СЛОВА: Myotis, зимовка, пещеры-штольни, температура, влажность, Россия.

\section{Introduction}

The bat fauna of the Leningrad Region is quite diverse compared to other regions of European Russia in similar latitudes. The reasons for that are both a considerable ingression of nemoral elements onto the boreal zone and the near maritime climate, and an ample supply of hibernacula. In general, eleven chiropteran species are known from the region (Airapety- ants et al., 1987), four of which are migratory, and seven hibernate at the same latitudes as their summer habitats. Five of them belongs to the Mouse-eared bats of genus Myotis Kaup, 1829: Myotis dasycneme (Boie, 1825) - pond myotis, M. daubentonii (Kuhl, 1817) Daubenton's myotis, M. nattereri (Kuhl, 1817) — Natterer's myotis, M. brandtii Eversman, 1845 — Brandt's myotis, and M. mystacinus (Kuhl, 1817) — whiskered myotis. Mouse-eared bats preferred hibernacula are 


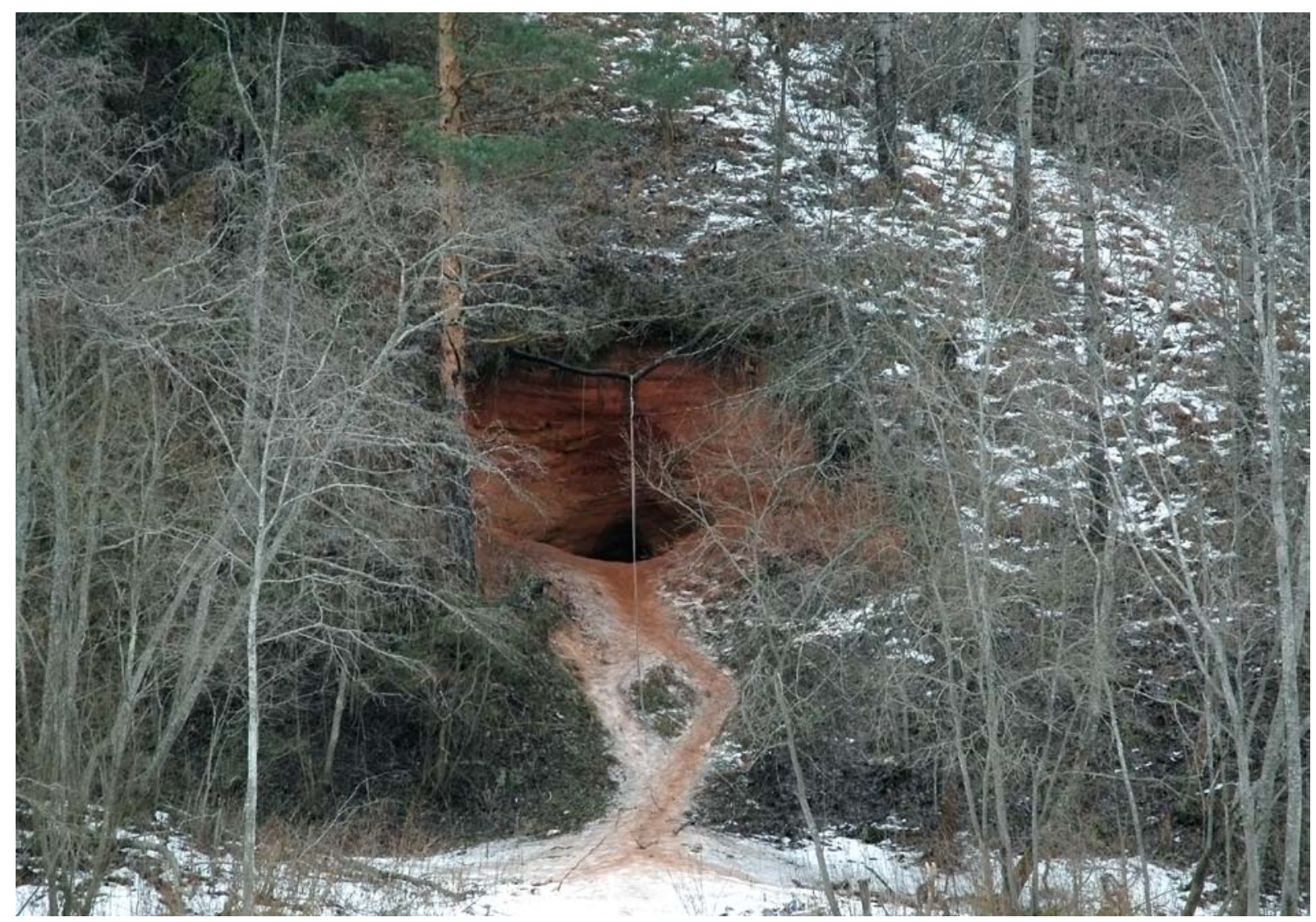

Fig. 1. Entrance of the artificial Borshchevskaya Cave (Leningrad Region, Luzhskii District, vicinity of Borshchevo Village (February, 2008). The Cave formed as a result of quartz sand mining for a Tarkovich Glass Manufacture.

caves or other underground shelters with similar conditions.

All mouse-eared bat species are unevenly distributed across the region, vary in abundance, and used different hibernacula. The distribution of massive aggregations of hibernating bats is directly associated with the locations of artificial caves (Strelkov, 1958; Il'in \& Smirnov, 2000; Il'in et al., 2003; Bogdarina, 2003, Kovalev et al., 2014).

This paper is an overview and analysis of observations carried out in previous decades, including the author's own surveys from 2007-2015, covering the hibernacula of mouse-eared bats in artificial caves of the Leningrad Region, which is quite extensive on the European scale and quite distinct in terms of climate and biogeography.

The aim of the study was to identify patterns in the distribution and abundance dynamics of various mouseeared bat species in underground hibernacula, and the effect of hibernation in artificial caves on the total size of the populations. Tasks of paper are: (a) counts of different mouse-eared bat species in all known artificial caves; (b) determining of the structural and microclimatic features of the hibernacula; (c) determining of the relations between the hibernacula and surrounding habitats; (d) preliminary estimation of a different values of the inter- and intraspecies abundances; (e) risk estimation of hibernation period.

\section{Material and methods}

Bat's shelters. Bats of the studied region use caves, underground fortifications, wells and other artificial places, basements and attics of residential buildings for hibernate. Probably most caves of the Leningrad Region appeared as a result of quartz sand mining for a glass-making industry since the early 19th to the mid20th century (Fig. 1). Some caves (e.g. Telezskije) appeared as result of the mining of quality artistic limestone. Limestone excavation formed abandoned artificial galleries of variable sizes, from 1 to $3 \mathrm{~m}$ in width, and 0.5 to $3 \mathrm{~m}$ in height, with some halls up to 15 $\mathrm{m}$ in diameter and 5-8 $\mathrm{m}$ of height. There are no natural caves in the Leningrad Region, apart from several small caverns worked by streams in steep river banks. Numerous old fortifications are presented on the Gulf of Finland shores and islands. Half of them are ruined or dilapidated.

Thus, annual counts were organized to regularly monitoring mouse-eared bat bats hibernating in artificial caves. During eight seasons from 2007 to 2015 we 


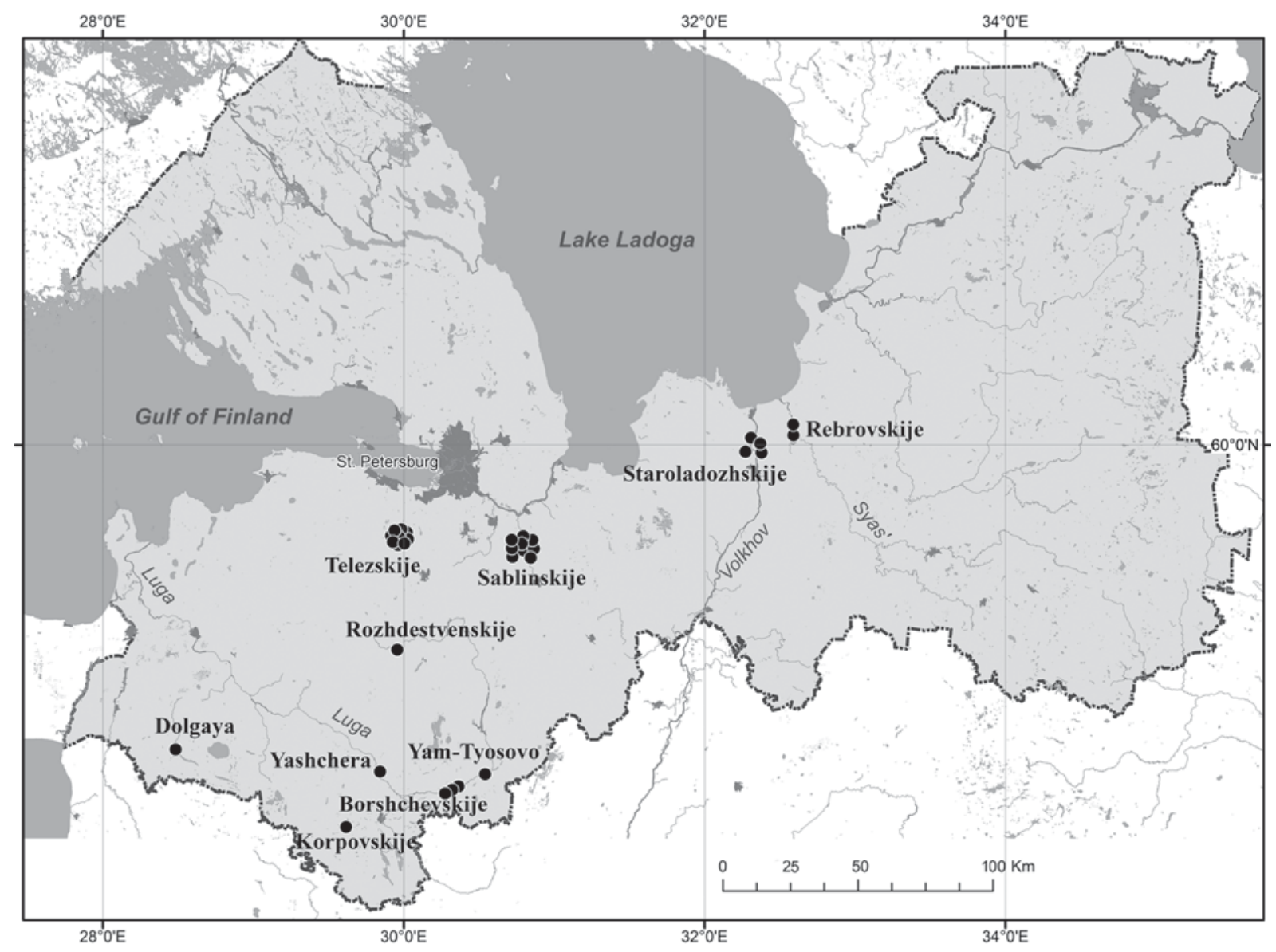

Fig. 2. Map of the geographic position of the underground hibernacula of Myotis bats in the Leningrad Region. Also see Table 1.

surveyed about 35 artificial caves/cavities per year. The most significant and representative in information were hibernaculi from follow group of caves: Sablinskije, Staroladozhskije, Borshchevskije, Rebrovskije, Korpovskije, and Telezskije (Fig. 2, Tab. 1).

All the caves were surveyed with making of detailed charts of 1:500 scale. The places with animals and it groups were mapped to avoid of undercounts and duplication of counts. Special detail studies with schema drawing (as example) have been performed for Tanechkina Cave. The schema is shown in Figure 2B. This cave is positioned on the steep left bank of the Volkhov River, and has two entrances 30 meters apart. These entrances facing to SW. One of them is located in the channel of the stream flowing into the Volkhov River. Another entrance is on the slope of this stream (Fig. 3). Tanechkina Cave appeared as result of the mining of quartz sands, and were abandoned over 150 years ago. The total length of all galleries over than $5500 \mathrm{~m}$, the cave area about $10720 \mathrm{~m}^{2}$. The outline in plane is irregular oval; the greater length is about $200 \mathrm{~m}$, width vary between 40 and $100 \mathrm{~m}$. Underground lake seasonally fill from 45 to $60 \%$ of internal area of cave; its depth can reach $1.5 \mathrm{~m}$. A stream about $1.5 \mathrm{~km}$ of length fills the lake, and discharges entirely into the cave. Ceiling height from 0.7 to $2.6 \mathrm{~m}$, and rising up to $5.5 \mathrm{~m}$ at scree areas. Originally, the ceiling height was even throughout the cave $-2.8 \mathrm{~m}$, but the stream filled the volume with sand and reduced the height.

Records from seven years of surveys at the hibernacula include: 10939 pond myotis, 2428 Daubenton's myotis, 1007 Natterer's myotis, 1009 Brandt's/whiskered myotis.

Shelters searching. Open source information from the Internet (see Appendix), archives of geological prospecting (unpublished data) and spelestological publications (Khazanovich, 1982), and own surveys were applied to searching of entrances to artificial caves. There are quite many amateur 'cavers' in the region, who look for caves and, specifically, for new entrances. Given the present-day information availability it is safe to say that it is feasible to annually survey all currently known accessible underground cavities. Preliminary surveys have shown that Myotis bats hibernate in all the artificial caves and in some grottoes.

My own and other specialist researches have been directed to find of mouse-eared bats in other places, such as fortifications and old water conduits. Generally 
Table 1. The geographic positions and physical characteristics of most known artificial caves and galleries of the Leningrad Region.

\begin{tabular}{|c|c|c|c|}
\hline $\mathbf{n}$ & Caves* & Coordinates & $\begin{array}{c}\text { Total length of } \\
\text { galleries (m) }\end{array}$ \\
\hline \multicolumn{4}{|c|}{ Group of Staroladozhskije Caves } \\
\hline 1 & Tanechkina & $\mathrm{N} 60^{\circ} 00^{\prime} \mathrm{E} 032^{\circ} 18^{\prime}$ & 5500 \\
\hline 2 & Underneath church & $\mathrm{N} 60^{\circ} 00^{\prime} \mathrm{E} 032^{\circ} 27^{\prime}$ & 410 \\
\hline 3 & Plachushchaya grot & $\mathrm{N} 60^{\circ} 00^{\prime} \mathrm{E} 032^{\circ} 18^{\prime}$ & 15 \\
\hline 4 & Plachushchaya hole & $\mathrm{N} 60^{\circ} 00^{\prime} \mathrm{E} 032^{\circ} 18^{\prime}$ & 488 \\
\hline \multicolumn{4}{|c|}{ Group of Rebrovskije Caves } \\
\hline 5 & Raschyoska & $\mathrm{N} 60^{\circ} 30^{\prime} \mathrm{E} 032^{\circ} 35^{\prime}$ & 240 \\
\hline 6 & Petrovskaya & $\mathrm{N} 60^{\circ} 30^{\prime} \mathrm{E} 032^{\circ} 35^{\prime}$ & 507 \\
\hline \multicolumn{4}{|c|}{ Group of Korpovskije Caves } \\
\hline 7 & Korpovskaya & $\mathrm{N} 58^{\circ} 42^{\prime} \mathrm{E} 029^{\circ} 36^{\prime}$ & 400 \\
\hline \multicolumn{4}{|c|}{ Group of Rozhdestvenskije Caves } \\
\hline 8 & Svyataya & $\mathrm{N} 59^{\circ} 48^{\prime} \mathrm{E} 029^{\circ} 57^{\prime}$ & 70 \\
\hline 9 & Grot & $\mathrm{N}^{2} 9^{\circ} 48^{\prime} \mathrm{E} 029^{\circ} 57^{\prime}$ & 11 \\
\hline \multicolumn{4}{|c|}{ Group of Borshchevskije Caves } \\
\hline 10 & Kupol & $\mathrm{N} 58^{\circ} 50^{\prime} \mathrm{E} 030^{\circ} 21^{\prime}$ & 30 \\
\hline 11 & Goticheskaya & $\mathrm{N} 58^{\circ} 50^{\prime} \mathrm{E} 030^{\circ} 21^{\prime}$ & 420 \\
\hline 12 & Dvenadtsatistolbovaya & $\mathrm{N} 58^{\circ} 50^{\prime} \mathrm{E} 030^{\circ} 21^{\prime}$ & 390 \\
\hline \multicolumn{4}{|c|}{ Group of Yam-Tyosovo Caves } \\
\hline 13 & Morovino & N58 $8^{\circ} 53^{\prime} \mathrm{E} 030^{\circ} 32^{\prime}$ & 10 \\
\hline \multicolumn{4}{|c|}{ Group of Telezskije Caves } \\
\hline 14 & Petrovskaya & $\mathrm{N} 59^{\circ} 41^{\prime} \mathrm{E} 029^{\circ} 58^{\prime}$ & 360 \\
\hline 15 & Blizhnyaya & $\mathrm{N} 59^{\circ} 41^{\prime} \mathrm{E} 029^{\circ} 58^{\prime}$ & 20 \\
\hline 16 & Lesnaya 1 & $\mathrm{~N} 59^{\circ} 41^{\prime} \mathrm{E} 029^{\circ} 58^{\prime}$ & 30 \\
\hline 17 & Kolokol & $\mathrm{N} 59^{\circ} 41^{\prime} \mathrm{E} 029^{\circ} 58^{\prime}$ & 5 \\
\hline 18 & Gorelaya & $\mathrm{N} 59^{\circ} 41^{\prime} \mathrm{E} 029^{\circ} 58^{\prime}$ & 10 \\
\hline 19 & Zal Gigantov & $\mathrm{N}^{2} 9^{\circ} 41^{\prime} \mathrm{E} 029^{\circ} 58^{\prime}$ & 40 \\
\hline 20 & Tortsevaya & $\mathrm{N}^{\prime} 9^{\circ} 41^{\prime} \mathrm{E} 029^{\circ} 58^{\prime}$ & 50 \\
\hline 21 & $\begin{array}{l}\text { Unnamed Cave (between } \\
\text { Lesnaya } 1 \text { and Tortsevaya) }\end{array}$ & $\mathrm{N} 59^{\circ} 41^{\prime} \mathrm{E} 029^{\circ} 58^{\prime}$ & 30 \\
\hline 22 & Lesnaya 2 & N5941' E029॰58' & 90 \\
\hline 23 & Yashchera & $\mathrm{N} 58^{\circ} 53^{\prime} \mathrm{E} 029^{\circ} 50^{\prime}$ & 10 \\
\hline 24 & Dolgaya & $\mathrm{N}^{2} 8^{\circ} 58^{\prime} \mathrm{E} 028^{\circ} 58^{\prime}$ & 21 \\
\hline \multicolumn{4}{|c|}{ Group of Sablinskije Caves } \\
\hline 25 & Levoberezhnaya & $\mathrm{N} 59^{\circ} 40^{\prime} \mathrm{E} 030^{\circ} 47^{\prime}$ & 6500 \\
\hline 26 & Grafskaya & $\mathrm{N} 59^{\circ} 40^{\prime} \mathrm{E} 030^{\circ} 48^{\prime}$ & 160 \\
\hline 27 & Zhemchuzhnaya & $\mathrm{N} 59^{\circ} 40^{\prime} \mathrm{E} 030^{\circ} 48^{\prime}$ & 550 \\
\hline 28 & Shtany & $\mathrm{N} 59^{\circ} 40^{\prime} \mathrm{E} 030^{\circ} 48^{\prime}$ & 1700 \\
\hline 29 & Veryovka & $\mathrm{N}^{\prime} 59^{\circ} 39^{\prime} \mathrm{E} 030^{\circ} 48^{\prime}$ & 800 \\
\hline 30 & Tryohglazka & $\mathrm{N}^{\prime} 59^{\circ} 40^{\prime} \mathrm{E} 030^{\circ} 47^{\prime}$ & 260 \\
\hline 31 & Lisja Nora 1 & $\mathrm{~N}^{2} 9^{\circ} 39^{\prime} \mathrm{E} 030^{\circ} 46^{\prime}$ & 17 \\
\hline 32 & Lisja Nora 2 & N59 $9^{\circ} 39^{\prime} \mathrm{E} 030^{\circ} 46^{\prime}$ & 12 \\
\hline 33 & Lisja Nora 3 & N59 $39^{\circ} \mathrm{E} 030^{\circ} 46^{\prime}$ & 79 \\
\hline
\end{tabular}

Note: summarized data based on revised materials from the Russian Society for Spelestological Research (http://rosi-spelesto.narod.ru).

these shelters did not contained bats. However some fortifications and water conduits were shelters for northern bat, Eptesicus nilssonii Keyserling et Blasius, 1839, and brown long-eared bat, Plecotus auritus (Linnaeus, 1758) (Chistyakov, 2004). Two specimens of Dauben- ton's myotis were observed in underground ruins of Fort Ino on the Gulf of Finland Northern Coast (Chistyakov, 1999, 2009).

To spot of potential position of hibernacula in other shelters (wells, basements, attics), conducted surveys 

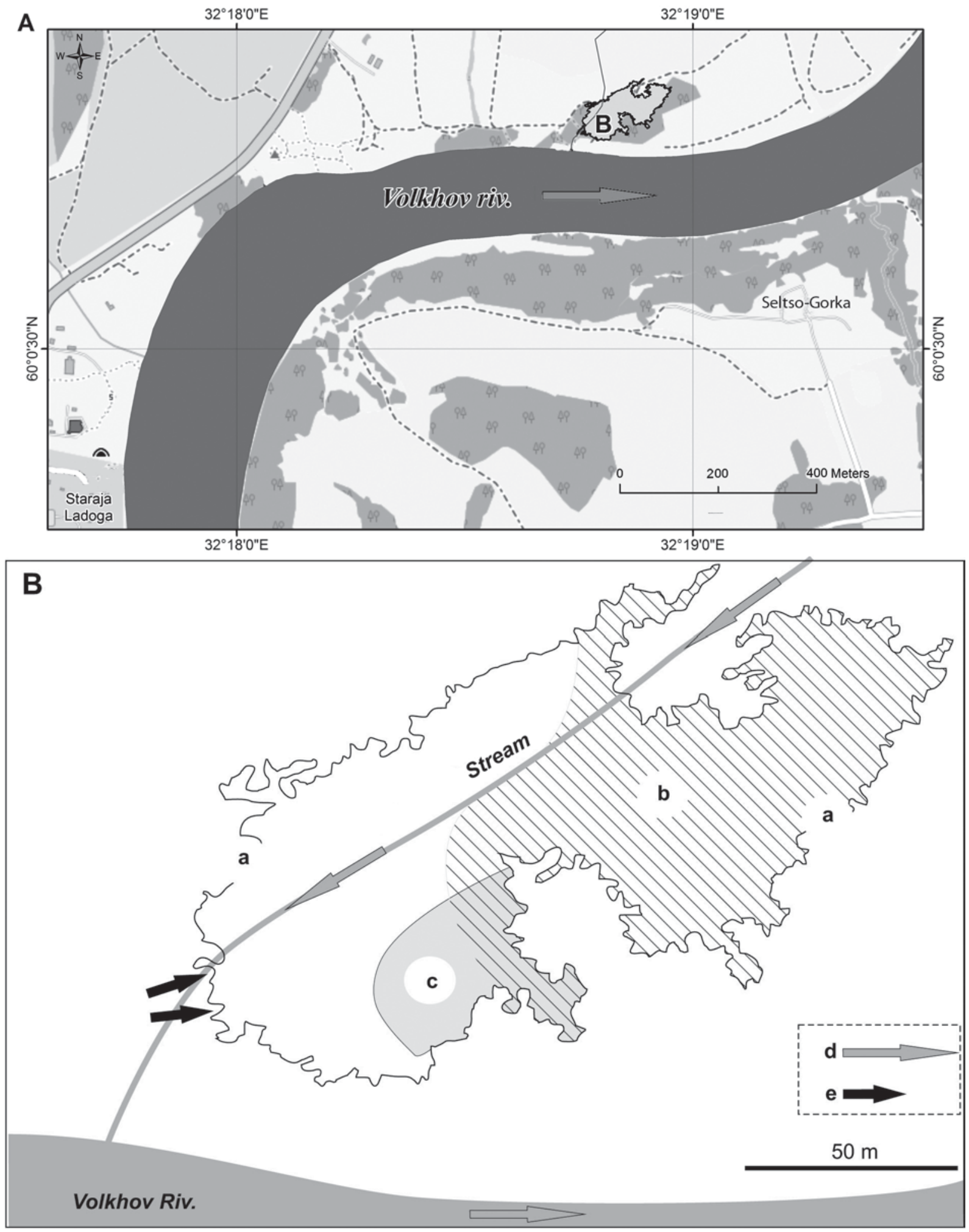

Fig. 3. Tanechkina Cave. A - map of the geographic position on the right bank of Volkhov River. B - plan of the Cave. Abbreviations: $\mathrm{a}$ - Cave outline; $\mathrm{b}$ - underground lake; $\mathrm{c}$ - pond myotis colony; $\mathrm{d}$ - stream direction; $\mathrm{e}$ - entrance. 
among the residing peoples around known bat habitats, in addition we viewed media for searching information about that. A special information was announced on the website of the Interregional non-governmental organization "Centre for Nature Conservation Research and Initiative" (http://naturconserv.org). As a result, brown long-eared bat hibernacula was found in well near to the Yelizavetino Village, where dead bats were sometimes observed in buckets.

Precautions and some species identification. As is now known, frequent arousals during hibernation may exhaust or even kills bats. To avoid this we have tried to minimized influence, and did not touch the sleeping animals. As result we could not distinguish specimens of two morphologically similar species Brandt's myotis and whiskered myotis. Therefore, specimens probably belonging to one of these species were further defined as "Brandt's/whiskered myotis".

The attempt to differentiate between hibernacula of these two species was based on examination of the skulls extracted from carcasses retrieved from different caves, morphological traits of individuals and the general appearance of the aggregations.

After the large colony of Brandt's/whiskered bats had been discovered in 2014, an attempt was made to find caves with hibernating whiskered myotis. Sixteen animals from large group in Telezskije caves were examined (10 $\sigma^{7} \sigma^{7} / 6$ 0 ), and additionally four skulls from the same caves were inspected. Identification was based on three traits: baculum shape; tooth row measurements (premolar size, shape and position), color of the base of tragus (Kozhurina, 1997). All the inspected individuals were identified as Brandt's myotis, and the skulls also belonged to this species. The generally uniform appearance of the animals in the dense aggregations suggests there were only Brandt's myotis. As to bats in the eastward Staroladozhskije Caves, inspection of the skulls of three dead animals and examination of six individuals $\left(3 \sigma^{7} \sigma^{\top} / 4+9\right)$ for the three above-listed traits showed that these caves did not harbour whiskered myotis either. The artificial caves may, in fact, be inhabited by whiskered myotis, but checking all the animals for the species affiliation has no big sense while involving a risk of killing the animals (Strelkov \& Buntova, 1982).

Population counts. Count of specimens of each hibernicula were performed from October to May. Each cave/cavity was examined from one to five times over a season. As a result of accountings it was found out that maximum population was reached in December. Analyses were performed by December's count, because in this month was maximum abundance. Annual variation was studied using data of December-February. Hibernacula population is most stable in these months. Bats are more readily visible against level sand walls. The crevices where some animals hide in are usually quite shallow. Both individually located animals and the size of groupings (including per each defined species) were recorded.
Tools. Temperature and humidity were measured in addition to animal counts. We used thermohygrometers RST 06018 (Sweden, China). In additions, in some cases we described elevation of specimen groups relatively of floor level, type of surface where the animals located (wall, ceiling), and using of micro-shelters (crevices, niches) or open space of surfaces. All measurements were performed with using tape-line. Biotopes around the hibernacula were surveyed for bat presence before the winter season (till the start of bats hibernation). We used special bat detector - Pettersson Elektronik D-200 (Sweden) that allowed to estimates of summer count and abundance in specific places (results were published, see details in Kovalyov \& Popov, 2011; Kovalyov \& Shchekhovsky, 2014).

\section{Results}

Pond myotis. Specimens of this species were found in 13 caves out of 35 studied. In two of them pond myotis hibernated annually. Around $99 \%$ of all pond myotis in the study area hibernated in Tanechkina Cave of the Staroladozhskije Caves group (Tab. 2). Another studied caves and caverns with occasional meeting of pond myotis were situated either close to Tanechkina Cave or not so far from the bats' summer habitats (Tab. 2 ). According to information from other regions, the pond myotis is more depending on temperature and humidity conditions through the hibernate period, than other bat species. The timeframe for the stay of pond bats in Tanechkina Cave is from late September to late May. Animals may keep entering the cave until late November and begin to emerge from the Cave in the first third of March (Kovalyov \& Popov, 2011).

The pond myotis colony occupies only part of Tanechkina Cave. It has a discrete location, and the core of the colony occupy about $1600 \mathrm{~m}^{2}$ (Fig. 3B). The temperature/humidity conditions of Tanechkina Cave have changed somewhat since the 1950s. According to Strelkov (1958), the temperature in this cave ranged +5 to $+7^{\circ} \mathrm{C}$, and air humidity was about $95 \%$ or higher. At present, the temperature that measured about $30 \mathrm{~m}$ from entrance is ranged +10 to $+12{ }^{\circ} \mathrm{C}$ during period from November to May, and pond myotis here hibernate at this temperature conditions. This temperature interval is much higher than the optimum for this species that described for Samarskaya Luka Dungeons (Smirnov et al., 2008). About $25 \%$ of individuals lodge on the walls and ceiling above underground lake surface, another part of colony lodge very close to water. About $5 \%$ of the individuals or their groups (before 50 bats) are placed outside the core of the colony in more remoted parts of the cave. Within the core the pond myotis are kept apart, and formed either small groups not more than 10 animals, or more large compact aggregations of up to 90 animals. These observations are consistent with results of Smirnov et al. (2012) for Mount Popov's artificial caves of Samarskaya Luka, where pond myotis showed a high degree of uneven distribution. Specif- 
Table 2. Results of annual counts of pond myotis in caves of the Leningrad Region during period 2008-2015.

\begin{tabular}{|c|l|c|c|c|c|c|c|c|c|}
\hline $\mathbf{n}$ & \multicolumn{1}{|c|}{ Caves } & $\mathbf{2 0 0 8}$ & $\mathbf{2 0 0 9}$ & $\mathbf{2 0 1 0}$ & $\mathbf{2 0 1 1}$ & $\mathbf{2 0 1 2}$ & $\mathbf{2 0 1 3}$ & $\mathbf{2 0 1 4}$ & $\mathbf{2 0 1 5}$ \\
\hline 1 & Staraya Ladoga, Tanechkina & 934 & 1228 & 1297 & 1784 & 1180 & 1922 & 1168 & 1301 \\
\hline 2 & $\begin{array}{l}\text { Staraya } \\
\text { Ladoga,Plachushchaya grot }\end{array}$ & 1 & 0 & - & - & 1 & 0 & 2 & 2 \\
\hline 3 & $\begin{array}{l}\text { Staraya Ladoga, } \\
\text { Plachushchaya hole }\end{array}$ & - & - & - & - & 10 & 8 & - & - \\
\hline 4 & Korpovskaya & 6 & 6 & 4 & 3 & 2 & 2 & 2 & 0 \\
\hline 5 & $\begin{array}{l}\text { Borshchevo, } \\
\text { Dvenadtsatistolbovaya }\end{array}$ & 7 & 0 & 0 & 0 & 0 & 0 & 0 & 0 \\
\hline 6 & Yam-Tyosovo, Morovino & 1 & 0 & 0 & 0 & 0 & 0 & 0 & 0 \\
\hline 7 & Telezi, Petrovskaya & 0 & 1 & 0 & 0 & 0 & - & 5 & - \\
\hline 8 & Telezi, Zal Gigantov & - & - & - & - & - & - & 5 & 0 \\
\hline 9 & Telezi, Tortsevaya & - & - & - & - & - & - & 4 & 0 \\
\hline 10 & Telezi, Lesnaya 2 & - & - & - & - & - & - & 18 & 1 \\
\hline 11 & Sablino, Zhemchuzhnaya & 0 & 0 & 0 & - & 0 & - & 6 & 1 \\
\hline 12 & Sablino, Levoberezhnaya & 1 & 6 & 0 & - & 3 & - & 4 & 2 \\
\hline 13 & Sablino, Shtany & - & 1 & - & - & 0 & 2 & 3 & 1 \\
\hline 14 & Sablino, Lisja nora 1 & - & 0 & - & - & 2 & - & 0 & 0 \\
\hline 15 & Sablino, Lisja nora 2 & - & 0 & - & - & 1 & - & - & - \\
\hline 16 & Sablino, Lisja nora 3 & - & 2 & - & - & 0 & - & 0 & 0 \\
\hline
\end{tabular}

Note: "-" — no data; "0" — bats not found.

ic characters of the local distributions of this species are occupation of open surface; if some of the biggest aggregations occupy shallow crevices, then all individuals have access to the open space of the cave. In addition, during hibernation season animals occasionally can change personal location, and these rearrangements lead to some alterations of group's size.

The studied hibernating colonies (hibernaculi) were described with using two parameters: number of groups and their size (number of animals in each group). The relatively distribution of individuals among groups proved to be quite accurately described by the power function with negative fractional exponent. The approximation confidence factor $\left(\mathrm{R}^{2}\right)$ was near one. This was a typical distribution in any cases when the number of individuals in the cave was between 500 and 1900 (Fig. 4A,B).

Six size classes can be allocated for pond myotis that hibernating in large colonies. Each of classes differs in attachment possibilities, thermoregulation ability, and sex-age characteristics. These classes are: single animals; pairs; small groups from 3 to 10 individuals (each animals of single-small group has lateral contact with environments); middle-sized group from 11 to 30 individuals, where part of them surrounding the group, and where they do not have problems with the attachments; large group from 31 to 50 individuals, where animals have some problems with the attachments on the flat surfaces of walls and ceiling; very large group with more than 50 individuals, forming with exclusive attachment options, often located in crevices.

The ratio of groups of different size in the hibernaculum was more constant than the ratio of individuals belonging to these categories. The shares of single individuals and pairs usually remained constant. The most numerous size classes were single individuals, and small groups with 3 to 10 individuals. Each of the three classes with 3-50 animals (small-middle-large) was represented by a relatively stable number of hibernating bats, roughly a third of its total abundance. In years of maximum of population, groups bigger than 50 individuals appear, and the number of individuals hibernating in groups increased from 11 to 30 .

Examination of the 30 single individuals showed that males slightly dominate in numbers $\left(18 \sigma^{\top} \sigma^{\top} / 12\right.$ \% + ). Four groups with 2, 6, 13, 35, correspondingly, showed nearly equal proportion of males and females number (total examination $270^{7} \sigma^{7} / 29+\%$ ). The group distribution structure during hibernate and during emergence of pond myotis from the cave varied less significantly compared to variations among years, and was not related to abundance. Thus, although grouping structure does not show whether the hibernaculum has reached its maximum, one can still estimate the abundance in the hibernaculum without doing a full census. 

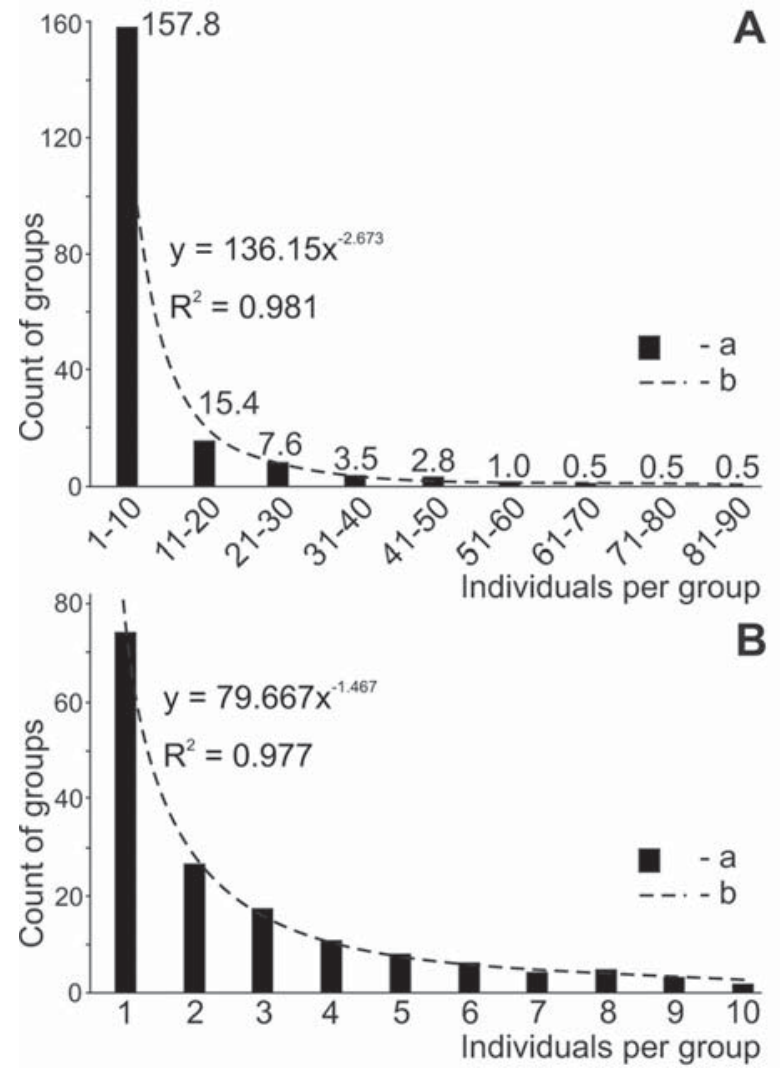

Fig. 4. The distribution of the mean number of pond myotis groupings of different size (A); and groupings with comprising from 1 to 10 animals (B). Total count of animals ranged 500 to 1900 animals (nine repeats of abundance estimation). Abbreviations: $a$ - counts of groups; $b$ - the power function (see detail in text).

Numbers of pond myotis that were found in Tanechkina Cave (Fig. 5), as the preferred species habitat, have increased considerably since the 1950s (Fig. 6). The abundance has doubled also in the years of our surveys (Fig. 7A). It is noteworthy that after the abundance threshold in the Tanechkina Cave had been approached, the number of hibernating bats the next year dropped to around 1200. High abundance years were also noted for an early (March) beginning of emergence of a considerable part of bats from the cave. At the same time, the number of dead bodies found during emergence was also high (up to 60).

Summer habitats of pond myotis are situated 150 $\mathrm{km}$ or more from the hibernaculum in Tanechkina Cave (see details in Kovalyov \& Popov, 2011). No pond myotis have been observed around the key hibernaculum from May to September. A few bats were registered within the audible range of the detector $(80 \mathrm{~m})$ not far from the cave in October, before they entered the hibernaculum. The rest of the caves where the pond myotis was found to hibernate were situated either in the same area as summer habitats or along autumn migration routes (Kovalyov \& Popov, 2011; Kovalyov, 2011).

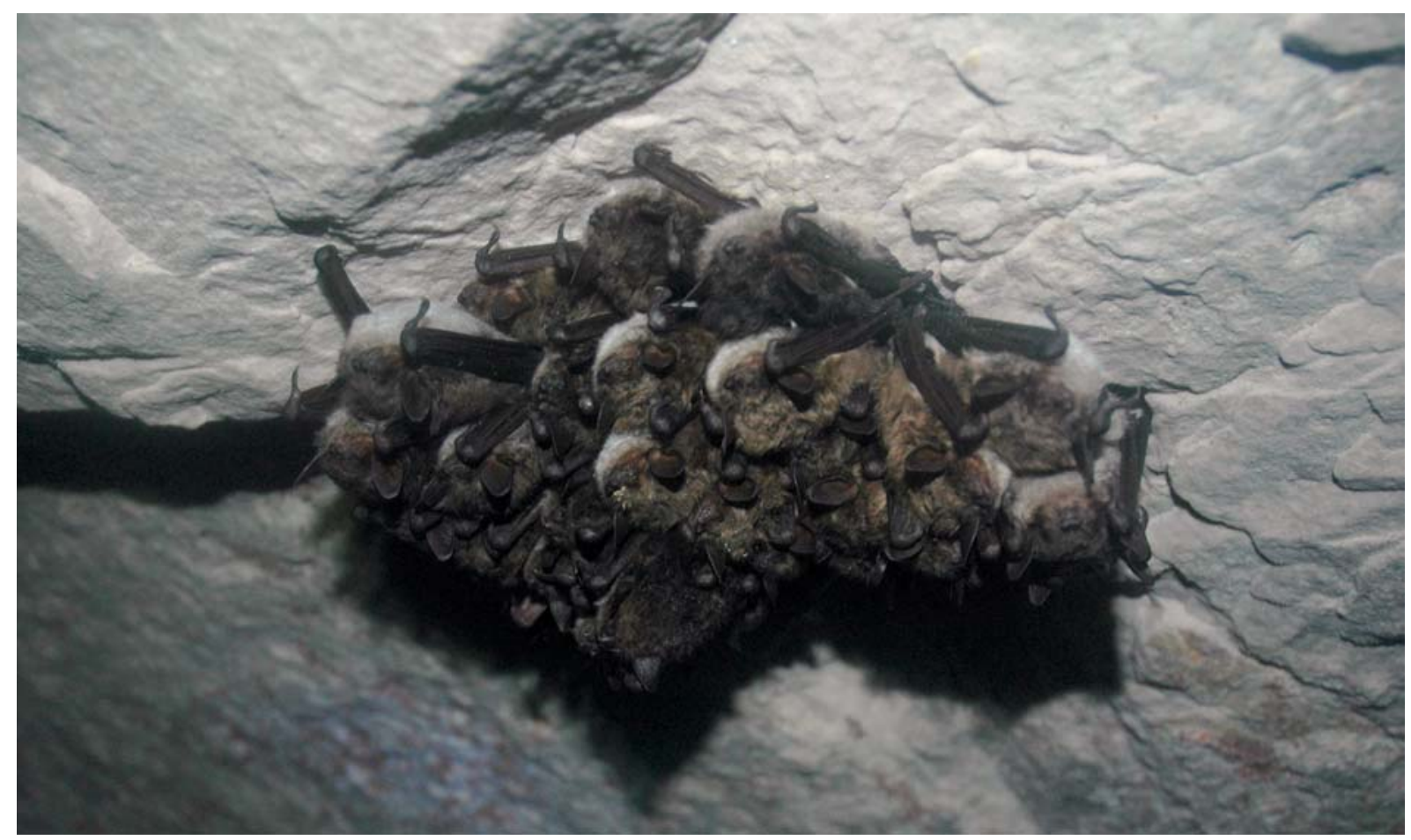

Fig. 5. Group of pond myotis in the Tanechkina Cave (January, 2011). (C) I. Popov 2008. 


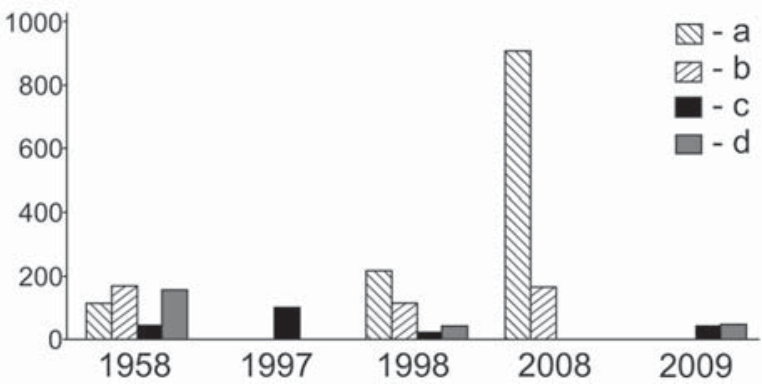

Fig. 6. Results of the estimation of the number of the different species of Myotis bats within caves of the Leningrad Region during last 60 years according to published data (Strelkov, 1958; Iljinsky et al., 1998; Chistyakov et al., 1999; Kovalyov \& Popov, 2011). Abbreviations: a — pond myotis (Tanechkina Cave); b - Daubenton's myotis (Tanechkina Cave); c - Natterer's myotis (Levoberezhnaya Cave); $\mathrm{d}$ - Brandt's/whiskered myotis (Staroladozhskije and Sablinskije Caves).
Daubenton's myotis. Specimens of this species were found in 16 caves out of the 35 , and were present in ten caves at each estimation of abundance during 2008-2015 (Tab. 3). On average, around 70\% of all hibernating animals of this species were found in Tanechkina Cave. The rest 30\% were distributed quite evenly among all major groups of caves (except Telezskije Caves). Hibernaculum conditions in Tanechkina Cave were described above. Daubenton's myotis were evenly scattered throughout the cave from the entrance, where the temperature on frosty days was near $0^{\circ} \mathrm{C}$, to the farthest premises. Up to $80 \%$ of the single animals occupy the open surface of walls and ceiling above dry floor either open water of underground lake. Another $20 \%$ of the animals formed groups from 2 to 5 , and occasionally specimens Daubenton's myotis were detected within groups of pond myotis. This ratio $(80 / 20)$ here remained stable during several years. In other caves Daubenton's myotis were also mostly staying individually. A similar single distribution of this species was observed in the Samarskaya Luka Dungeons.

The microclimate conditions in different known Daubenton's myotis hibernaculum varied widely: temperature ranged from 1 to $12^{\circ} \mathrm{C}$, humidity from $70 \%$ to

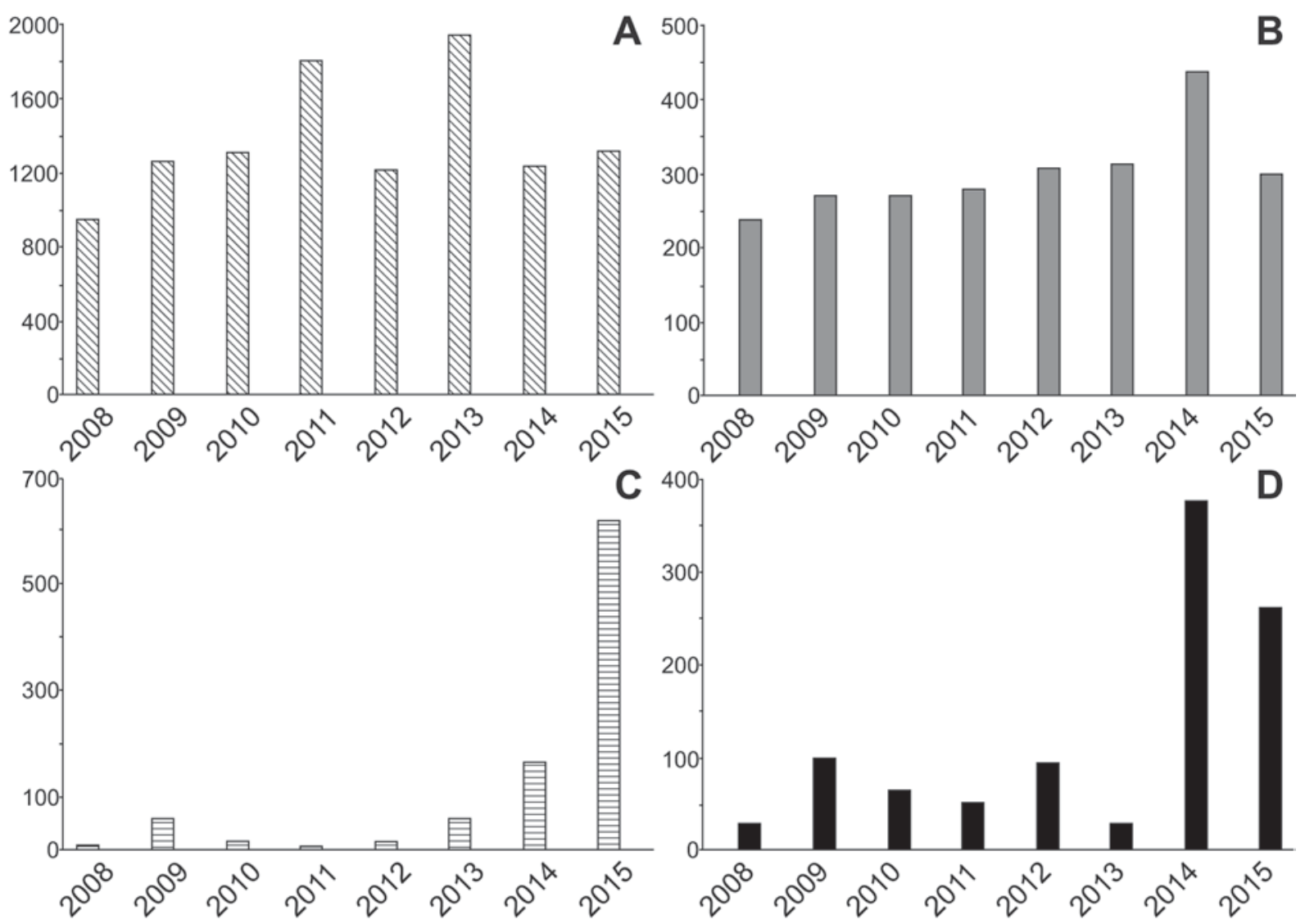

Fig. 7. Total number of individuals of the different species of Myotis bats counted in caves of the Leningrad Region during period 2008-2015. A - pond myotis, B - Daubenton's myotis, C - Natterer's myotis, D — Brandt's/whiskered myotis. Abbreviations: OX - years; OY — number of animals. 
Table 3. Results of annual counts of Daubenton's myotis in caves of the Leningrad Region during period 2008-2015.

\begin{tabular}{|c|l|c|c|c|c|c|c|c|c|}
\hline $\mathbf{n}$ & \multicolumn{1}{|c|}{ Caves } & $\mathbf{2 0 0 8}$ & $\mathbf{2 0 0 9}$ & $\mathbf{2 0 1 0}$ & $\mathbf{2 0 1 1}$ & $\mathbf{2 0 1 2}$ & $\mathbf{2 0 1 3}$ & $\mathbf{2 0 1 4}$ & $\mathbf{2 0 1 5}$ \\
\hline 1 & Staraya Ladoga, Tanechkina & 165 & 189 & 219 & 199 & 199 & 218 & 302 & 189 \\
\hline 2 & $\begin{array}{l}\text { Staraya Ladoga, Underneath } \\
\text { church }\end{array}$ & 5 & 10 & 9 & 11 & 6 & 6 & 14 & - \\
\hline 3 & $\begin{array}{l}\text { Staraya Ladoga, } \\
\text { Plachushchaya grot }\end{array}$ & 0 & 0 & - & - & 1 & 1 & 2 & - \\
\hline 4 & $\begin{array}{l}\text { Staraya Ladoga, Plachushchaya } \\
\text { nora }\end{array}$ & - & - & - & - & 27 & 24 & 0 & - \\
\hline 5 & Rebrovskaya, Raschyoska & 7 & 12 & - & 18 & 9 & 6 & 12 & - \\
\hline 6 & Rebrovskaya, Petrovskaya & 14 & 5 & - & 19 & 4 & 18 & 41 & - \\
\hline 7 & Korpovskaya & 30 & 26 & 28 & 27 & 26 & 17 & 20 & - \\
\hline 8 & Rozhdestveno, Grot & 0 & 1 & - & - & 1 & - & 0 & - \\
\hline 9 & Borshchevo, Goticheskaya & 9 & 8 & 10 & 4 & 10 & 11 & 27 & 13 \\
\hline 10 & $\begin{array}{l}\text { Borshchevo, } \\
\text { Dvenadtsatistolbovaya }\end{array}$ & 2 & 2 & 6 & 4 & 6 & 4 & 6 & 8 \\
\hline 11 & Telezi, Tortsevaya & - & - & - & - & - & - & 1 & 2 \\
\hline 12 & Dolgaya & 0 & 1 & - & - & 1 & - & 0 & - \\
\hline 13 & Sablino, Levoberezhnaya & 3 & 5 & 1 & - & 18 & - & 13 & 70 \\
\hline 14 & Sablino, Zhemchuzhnaya & 1 & 7 & - & - & 1 & 4 & - & 6 \\
\hline 15 & Sablino, Shtany & - & 2 & - & - & 1 & 6 & 1 & 12 \\
\hline 16 & Sablino, Lisja nora 3 & - & 3 & - & - & 0 & - & 0 & 2 \\
\hline
\end{tabular}

Note: see in Table 2.

$100 \%$. On some occasions, Daubenton's myotis hibernated within groups of northern bat, when the temperature temporarily dropped below $0^{\circ} \mathrm{C}$, and no other bat species were present. For instance, they were found in Dolgaya Cave and Fort Ino (Chistyakov, 2009).

From the 1950s to 2008 the Daubenton's myotis abundance at most hibernacula in the Leningrad Region has apparently remained fairly constant. A noteworthy fact however is a substantial reduction in their numbers in the group of Sablinskije Caves (Fig. 6). The abundance of Daubenton's myotis in Tanechkina Cave, as the preferred species habitat, was slightly increasing (Fig. 6). An upward trend in the abundance of it has been observed during the period of this study in all caves. The rise was especially significant in 2014 (Fig. 7B).

The summer habitats of Daubenton's bats are situated around most of the caves with their hibernacula (as observed by the author).

Natterer's myotis. Specimens of this bat were found in 11 caves out of the 35 , and were present in three caves at each estimation of abundance during 20082015 (Tab. 4). Compare to another species, hibernating specimens of Natterer's myotis were observed only in two groups of caves - Telezskije and Sablinskije. Around $90 \%$ of the animals were found in Sablinskije Caves (mainly in Levoberezhnaya). Levoberezhnaya
Cave characterized by the following environmental conditions: temperature ranged from 8 to $12^{\circ} \mathrm{C}$; humidity from 74 to $100 \%$. Natterer's myotis there hibernated under two types of conditions depending on the distance from the entrance: $60 \%$ of individuals hibernating in distance from 20 to $100 \mathrm{~m}$ from entrance were exposed to a temperature of 8 to $10^{\circ} \mathrm{C}$ and humidity of 74 to $93 \%$; another $40 \%$ than hibernating in distance from further than $100 \mathrm{~m}$ from one were exposed to a temperature of 10 to $12^{\circ} \mathrm{C}$ and humidity of 90 to $100 \%$. The most Natterer's myotis hibernated in crevices above dry areas of the Cave. A part of individuals occupied open flat surfaces of walls and ceiling, and often above open water; many animals were hanging on a wet ceiling with dripping water (either in deep horizontal crevices or openly). A lighted tourist path was set up in the first part of the cave, whereas no visitors were allowed into the second part. Around $70 \%$ of the animals stayed individually, up to $20 \%$ roosted in pairs, the biggest groupings comprised 4 individuals. Only in 2015, after a significant increase number Natterer's myotis was observed five groups of more than 10 individuals (1124). In Telezskije Caves and the similar Lisja Nora-3 Cave Natterer's myotis hibernated at a temperature of 4 to $6^{\circ} \mathrm{C}$ and humidity of 60 to $75 \%$.

The Natterer's myotis abundance at hibernacula in the Leningrad Region has fluctuated between the 1950s 
Table 4. Results of annual counts of Natterer's myotis in caves of the Leningrad Region during period 2008-2015.

\begin{tabular}{|c|l|c|c|c|c|c|c|c|c|}
\hline $\mathbf{n}$ & \multicolumn{1}{|c|}{ Caves } & $\mathbf{2 0 0 8}$ & $\mathbf{2 0 0 9}$ & $\mathbf{2 0 1 0}$ & $\mathbf{2 0 1 1}$ & $\mathbf{2 0 1 2}$ & $\mathbf{2 0 1 3}$ & $\mathbf{2 0 1 4}$ & $\mathbf{2 0 1 5}$ \\
\hline 1 & Telezi, Petrovskaya & 0 & 3 & - & 3 & 0 & - & 6 & - \\
\hline 2 & Telezi, Blizhnaya & 0 & 0 & - & 1 & 0 & - & - & 4 \\
\hline 3 & Telezi, Proval & 0 & 4 & - & - & 0 & - & - & - \\
\hline 4 & Telezi, Lesnaya 1 & - & 0 & - & - & 1 & - & 3 & - \\
\hline 5 & Telezi, Zal Gigantov & - & - & - & - & - & - & 3 & - \\
\hline 6 & Telezi, Tortsevaya & - & - & - & - & - & - & 3 & 3 \\
\hline 7 & Telezi, Lesnaya 2 & - & - & - & - & - & - & 5 & 3 \\
\hline 8 & Sablino, Levoberezhnaya & 9 & 43 & 17 & - & 106 & - & 124 & 503 \\
\hline 9 & Sablino, Zhemchuzhnaya & - & 5 & - & - & 6 & 5 & 8 & 56 \\
\hline 10 & Sablino, Shtany & - & 4 & - & - & 7 & 12 & 10 & 46 \\
\hline 11 & Sablino, Lisja nora 3 & - & 0 & - & - & 0 & - & 4 & - \\
\hline
\end{tabular}

Note: see in Table 2.

and 2009, yet remaining at about the same level. The most complete data have been gathered for Levoberezhnaya Cave of the group of Sablinskije Caves. The highest abundance there was recorded in 1997, before the tourist route was opened, and the number of the animals decreased dramatically in the following year (Fig. 6). During the study period, the Natterer's myotis abundance has been slightly growing in all caves. Comparable data were obtained in 2009, 2012, 2014 and 2015, and no surveys were carried out in Levoberezhnaya Cave in other years (Fig. 7C).

Brandt's/whiskered myotis. Specimens of this species complex were found in 22 caves out of the 35 , and were present in three caves at each estimation of abundance during 2008-2015, and observed in all groups of caves (Tab. 5). Prior to 2014, around 50\% were recorded from Staroladozhskije Caves, and about $25 \%$ in each of Sablinskije and Telezskije caves. In 2014, $75 \%$ of all the animals were found in Telezskije Caves. The reason for the change was the discovery of four new entrances to Telezskije Caves, where major aggregations of the bats were situated. Non-professional cavers encountered bats every time they discovered a new entrance. Hence, bats must have been able to get into the caves through small openings unsuited for humans. In all the caves Brandt's/whiskered myotis hibernated not far from entrances at a temperature of 3 to $6^{\circ} \mathrm{C}$, and humidity of 60 to $80 \%$. Where the colony was small in size, Brandt's/whiskered myotis were attached individually. If a cave contained more than 20 bats, part of the animals clumped together in groups of up to 10 . Where abundances were higher, the animals formed large dense aggregations of up to 50 individuals. Single individuals and small groups preferred secretive locations, in crevices or on small benches, and rarely stayed on open flat surfaces. Larger aggregations chose to stay openly.
Brandt's/whiskered myotis preferred dry conditions in a hibernaculum, and hardly ever hibernated above water.

Brandt's/whiskered myotis abundance at hibernacula in Staroladozhskije and Sablinskije caves had declined from the 1950s to 2009 (Fig. 6). During the study period until 2014 the average abundance remained quite constant, with a decline in Staroladozhskije and an insignificant rise in Sablinskije Caves. Comparable data for Staroladozhskije and Sablinskije caves were obtained in 2009, 2012, 2014 and 2015, since in other years Levoberezhnaya Cave was not surveyed. The large Brandt's/whiskered myotis colony newly discovered in Telezskije Caves in 2014, 2015 yielded a 3.5fold increase in the species abundance at the hibernacula (Fig. 7D).

\section{Discussion}

The analysis of the distribution of mouse-eared bats among hibernacula showed that the Natterer's myotis, pond myotis, and complex Brandt's/whiskered myotis had 2-3 constantly preferred caves, although minor numbers of individuals of these species may in some years be distributed quite widely. Daubenton's myotis were less strictly attached to specific shelters, hibernating in all groups of caves over years. Noteworthy is the greater number of caves with non-annual hibernacula of Brandt's/whiskered myotis as compared to other species. This may indirectly point to the hibernation of both species there: Brandt's myotis and whiskered myotis (Tab. 7A).

Previously available information and the our results show that caves and artificial caves are by far the only hibernation habitat for the pond myotis under the climatic conditions of its Russian distribution range (Strelk- 
Table 5. Results of annual counts of Brandt's/whiskered myotis in caves of the Leningrad Region during period 2008-2015.

\begin{tabular}{|c|c|c|c|c|c|c|c|c|c|}
\hline $\mathrm{n}$ & Caves & 2008 & 2009 & 2010 & 2011 & 2012 & 2013 & 2014 & 2015 \\
\hline 1 & Staraya Ladoga, Tanechkina & 22 & 20 & 51 & 41 & 40 & 18 & 16 & 39 \\
\hline 2 & $\begin{array}{l}\text { Staraya Ladoga, } \\
\text { Plachushchaya grot }\end{array}$ & 4 & 0 & - & - & 1 & 0 & 0 & 0 \\
\hline 3 & $\begin{array}{l}\text { Staraya Ladoga, } \\
\text { Plachushchaya hole }\end{array}$ & - & - & - & - & 0 & 3 & 0 & 0 \\
\hline 4 & Rebrovskaya, Raschyoska & 0 & 5 & - & 0 & 0 & 1 & 1 & 0 \\
\hline 5 & Rebrovskaya, Petrovskaya & 0 & 3 & - & 0 & 0 & 1 & 6 & 0 \\
\hline 6 & Korpovskaya & 1 & 6 & 3 & 2 & 1 & 0 & 0 & - \\
\hline 7 & Rozhdestveno, Svyataya & 0 & 1 & - & - & 0 & - & 0 & 0 \\
\hline 8 & Borshchevo, Goticheskaya & 2 & 0 & 0 & 0 & 1 & 2 & 1 & 1 \\
\hline 9 & $\begin{array}{l}\text { Borshchevo, } \\
\text { Dvenadtsatistolbovaya }\end{array}$ & 0 & 0 & 0 & 1 & 1 & 0 & 0 & 0 \\
\hline 10 & Telezi, Petrovskaya & 1 & 8 & 2 & 3 & 1 & - & 6 & - \\
\hline 11 & Telezi, Blizhnaya & 0 & 22 & 0 & 5 & 1 & - & - & 2 \\
\hline 12 & Telezi, Lesnaya 1 & - & 8 & 2 & - & 6 & - & 10 & - \\
\hline 13 & Telezi, Kolokol & - & - & 1 & 0 & - & - & - & - \\
\hline 14 & Telezi, 5 & - & - & - & - & 2 & - & - & 1 \\
\hline 15 & Telezi, Zal Gigantov & - & - & - & - & - & - & 120 & - \\
\hline 16 & Telezi, Tortsevaya & - & - & - & - & - & - & 44 & 35 \\
\hline 17 & $\begin{array}{l}\text { Telezi, Telezi + (between } \\
\text { Tortsevaya and Lesnaya 2) }\end{array}$ & - & - & - & - & - & - & 4 & 2 \\
\hline 18 & Telezi, Lesnaya 2 & - & - & - & - & - & - & 105 & 82 \\
\hline 19 & Sablino, Levoberezhnaya & 0 & 21 & 6 & - & 40 & - & 48 & 68 \\
\hline 20 & Sablino, Zhemchuzhnaya & - & 3 & - & - & 1 & 1 & 2 & 14 \\
\hline 21 & Sablino, Shtany & - & 2 & - & - & 0 & 4 & 8 & 18 \\
\hline 22 & Sablino, Lisja Nora 3 & - & 0 & - & - & 0 & - & 5 & - \\
\hline
\end{tabular}

Note: see in Table 2.

ov, 1958, 1971a,b; Orlov, 1998, 1999; Kovalyov \& Popov, 2011). It is safe to say that the number of pond myotis hibernating in Tanechkina Cave is directly related to their abundance in the region. This becomes obvious when comparing their abundances in summer and winter habitats, given the limited availability of such habitats (Kovalyov \& Popov, 2011). The rise in the number of pond myotis counted at the hibernaculum in 2011 and 2013 was in line with an expansion of the summer range into the southern part of the Karelian Isthmus and expansion of the autumn aggregation on the northern coast of Finland Gulf to Kieper Ort Peninsula (Kovalyov, 2012). Early in the 2000s pond myotis first appeared (Siivonen \& Wermundsen, 2003) and a few individuals were found at hibernacula of the Southern Finland. These findings evidence an expansion of the species range within the region as result of a rising abundance of population core. At the same time when the number of wintering animals of the Tanechkina Cave reached 2000, the following year the number decreased to 1200 individuals. We believe the reasons are both the hibernaculum capacity and the availability of summer habitats suitable for spring migrations (Kovalyov \& Popov, 2011).

Table 6. Records of Myotis bats in caves during all previous studies (A), and period of our monitoring 2008-2015 (B).

\begin{tabular}{|l|c|c|}
\hline \multicolumn{1}{|c|}{ Species } & A & B \\
\hline Pond myotis & 13 & 2 \\
\hline Daubenton's myotis & 16 & 10 \\
\hline Natterer's myotis & 11 & 3 \\
\hline Brandt's/whiskered myotis & 22 & 3 \\
\hline
\end{tabular}


Table 7. Characteristics of the Myotis bats wintering in caves of Leningrad Region.

\begin{tabular}{|l|c|c|c|c|c|c|c|}
\hline \multicolumn{1}{|c|}{ Species } & T, ${ }^{\circ} \mathbf{C}$ & $\begin{array}{c}\text { Humi- } \\
\text { dity, } \\
\mathbf{\%} \%\end{array}$ & $\begin{array}{c}\text { Distance } \\
\text { from the } \\
\text { entrance, } \mathbf{m}\end{array}$ & $\begin{array}{c}\text { Preferred } \\
\text { aggregation, } \\
\text { individuals }\end{array}$ & $\begin{array}{c}\text { Surface } \\
\text { location }\end{array}$ & $\begin{array}{c}\text { Presence in } \\
\text { surroun- } \\
\text { ding } \\
\text { habitats }\end{array}$ & $\begin{array}{c}\text { Part of } \\
\text { the } \\
\text { Region }\end{array}$ \\
\hline $\begin{array}{l}\text { Pond } \\
\text { myotis }\end{array}$ & $10-12$ & $90-100$ & $>20$ & $10-50$ & $\begin{array}{c}\text { openly, } \\
\text { in crevices }\end{array}$ & absent & Eastern \\
\hline $\begin{array}{l}\text { Dauben- } \\
\text { ton's } \\
\text { myotis }\end{array}$ & $1-12$ & $70-100$ & 10 to 200 & $1-2$ & openly & present & $\begin{array}{c}\text { Eastern, } \\
\text { Central, } \\
\text { Western }\end{array}$ \\
\hline $\begin{array}{l}\text { Natterer's } \\
\text { myotis }\end{array}$ & $4-12$ & $60-100$ & 5 to 200 & $1-2$ & $\begin{array}{c}\text { openly, } \\
\text { in crevices }\end{array}$ & vary & Central \\
\hline $\begin{array}{l}\text { Brandt's/ } \\
\text { whiskered } \\
\text { myotis }\end{array}$ & $3-6$ & $70-80$ & 5 to 20 & $2-5$ & $\begin{array}{c}\text { openly, } \\
\text { in crevices }\end{array}$ & vary & Western \\
\hline
\end{tabular}

The fact that there were no known pond myotis colonies bigger than 1000 individuals (Kuzyakin, 1950; Strelkov, 1958; Masing, 1990; Orlov, 1999; Limpens et al., 1999; Limpens et al., 2000) suggests that the species is generally unlikely to form bigger colonies. Given that the distribution into groups at the hibernaculum in this cave is modeled by the power function, one can say that the group structure of the colony conforms to fractal laws, meaning that when the abundances rises, a self-similar structure is reproduced, where groups of 100 or more animals appear. This group size is limited by attachment possibilities, and obviously affects the hibernation success of individual animals in a large grouping. The fractal structure must also be a significant factor in the thermoregulation of all bats in the hibernaculum. By moving within and among groups of different size during the hibernation period bats maintain the temperature regime needed for a physiologically optimal hibernation. The high mortality found in the cave in the spring following abundance maximums is indirect evidence of ill-being in the hibernaculum. The chance of epidemics and other force majeure causes of high mortality among bats hibernating in a little visited cave is low.

Although the pond myotis has a wide distribution from Belgium to Northern Kazakhstan, the northern limit of its range running at around $\mathrm{N} 60^{\circ}$, individual specimens are marked up to $\mathrm{N} 64^{\circ}$, and the southern limit from $\mathrm{N} 44^{\circ}$ to $50^{\circ}$ (Kozhurina, 2009), the range is discontinuous, apparently due to concentration around massive hibernation areas (Strelkov, 1970; Limpens et al., 2000). One can thus speak of optimal pond myotis abundance in the region at 1600-1800 individuals, which has been reached, and the species started dispersing to other parts of the range. The main range expansion trend associated with the Tanechkina Cave hibernaculum is towards the south of the Karelian Isthmus and Southern Finland, as well as eastwards from the St. Petersburg - Luga line. The trend has been exhausted by now, as all suitable summer habitats have been occupied. Longer-range dispersals are apparently directed south-westwards, towards the Pskov Region and Estonia.

The number of Daubenton's myotis at hibernacula depends on the size of the cave. This correlation is broken only in the caves with no habitats in the surroundings (Telezskije Caves), or where the nuisance factor exceeds the acceptable threshold (most of Sablinskije Caves). In most caves Daubenton's myotis appear to arrive from the surrounding summer habitats. The exception is Tanechkina Cave. The number of animals in this cave considerably exceeds the capacity of the nearby biotopes, populated by two individuals per $1 \mathrm{~km}$ of river or up to 10 individuals per $1 \mathrm{~km}^{2}$ of waterbody (unpublished data). This cave gathers Daubenton's myotis from an at least $50 \mathrm{~km}$ radius.

Absolute abundances of Daubenton's myotis in the Leningrad Region cannot be directly estimated by counts at hibernacula in artificial caves. The temperature and humidity at which Daubenton's myotis hibernate in the caves range widely, the temperature sometimes being at zero. Hence, the species may stay in various shelters other than caves. The number of individuals in caves can however be a good indicator of the population abundance. Summer counts of Daubenton's myotis using geographical information analysis of suitable habitats in the region have estimated the species abundance at 4000-4500 individuals (Kovalyov \& Shchekhovsky, 2014). Thus, around $10 \%$ of the regional population that hibernates in caves.

For the Natterer's myotis this region is the northeastern limit of its distribution range (Kozhurina, 2009). Presence in only two groups of caves, microclimate preferences at hibernacula, steadily low rate of abundance growth after the establishment of favorable conditions in Levoberezhnaya Cave suggest with high probability that Natterer's myotis in the Leningrad Region chiefly hibernate in caves. Hence, their population in the region is fairly small, no more than 1000 individuals. Summer counts of the animals using bat detectors 
revealed only singular Natterer's myotis individuals, confirming their low abundance.

Unusually high increment of number of Natterer's myotis in the group of Sablinskije Caves in 2015 may be due to the fact that in the period 2014-2015, the most of Telezskije Caves were destroyed during the construction of the highway Saint-Petersburg - Tallinn. The movements of Natterer's myotis could be caused by destruction of the wintering places. Probably, they lived in those of Telezskije Caves which were destroyed during a roadwork and were not earlier examined because of inaccessibility for humans. But perhaps it is a natural process of resettlement from the Baltic States.

The hibernaculum in Telezskije Caves appears to be the key winter habitat of the Brandt's/whiskered myotis in the region. Given the limited amount of summer habitats, one can presume the species abundance in the region to be characterized by the number of individuals at hibernacula. According to some data, the area of underground cavities in Telezskije Caves yet closed to people is less than $25 \%$ of known spaces. Assuming that bats can reach these areas, inaccessible to people, the total abundance of the Brandt's myotis in Telezi Caves may be higher than in the counts, probably amounting to 600-700 animals. The size of the compact aggregations, up to 50 animals, indirectly evidences that more bats than counted hibernate in Telezi.

It is possible to estimate the Brandt's/whiskered myotis abundance relying on counts at hibernacula, in spite of the low temperature conditions they choose to stay at in caves. For instance, the noticeable decline since the 1950s in Staroladozhskije and Sablinskije caves must have been a direct consequence of the removal of many Brandt's Myotis from the caves, when only females (60 individuals) were sampled to be checked for pregnancy (Strelkov, 1971a). The fact that the Brandt's myotis has not recovered its former numbers in these caves even after 40 years suggests that the species abundance in the Leningrad Region is low and that there are no other hibernacula in the region. Which means that the total counts of the Brandt's myotis regional population is about 1000 animals. The Brandt's myotis is one of the most long-living bat species: the average life span being 15-20 years, some individuals may live up to 38 (Khritankov \& Ovodov, 2001). Given their longevity and low fecundity, the significance of each individual for the well-being of the population is very high. Decrease in number of Brandt's myotis in 2015 in Telezskije Caves is bound to destruction of their most part at construction of the highway SaintPetersburg-Tallinn. During this period, almost 2 times was increased the number of Brandt's myotis in Sablinskije Caves. Perhaps this is due to the movement of bats from broken Telezskije Caves.

Species preferences for hibernacula in Myotis bats. Comparing analyses of the hibernaculum preferences of the different Myotis bat species were revealed that the strictest demands for conditions at the hiber- naculum demonstrated by pond myotis. Natterer's myotis accept a relatively wide range of temperature and humidity conditions, yet within certain limits that within studied region are inherent only to caves. Brandt's/ whiskered myotis choose the coldest and least humid sites in caves, but require that these conditions remain stable. Daubenton's myotis hibernate at the most diverse conditions, caves not being their only habitats. Hibernation characteristics of the whiskered myotis cannot be judged by data from artificial caves, since only occasional individuals have been found there, and the species seems to prefer different winter shelters (Tab. 7).

Considering the numbers of animals at hibernacula and assessing the role of artificial caves in the life cycle of different species, one can say that pond myotis are rather vulnerable in spite of the relatively high abundance and steady growth of its population, because they are completely dependent on the state of a single cave. The most threatening is the situation for the Natterer's myotis and the Brandt's/whiskered myotis. Their abundances are low, and they are highly vulnerable in all winter habitats because they are prefers only one or two known caves. The species of least concern is the Daubenton's myotis, which hibernates in most of the caves and employs the widest range of microclimatic conditions. The vulnerability of the whiskered myotis cannot be determined relying on data from the hibernacula, at least in our study. In general, the anthropogenic factor positively influences hibernacula of bats as factor forming of shelters. The artificial caves and various buildings create the favorable conditions for expansion of areas of bats habitat and allow to reach high concentration on winterings (Ilyin et al., 2003; Chistiakov \& Nikulin, 2010). However, the shortcomings of the protection measures in large concentrations of bats can lead to the death of a large number of animals (Mitchell-Jones et al., 2007; Wermundsen, 2010; Kovalyov et al., 2012).

\section{Conclusions}

Studying of the Myotis bats hibernicula places in Leningrad Region applied to the following conclusions. Microclimate characteristics of the hibernacula are highly diverse, from 3 to $12^{\circ} \mathrm{C}$, and humidity from 60 to $100 \%$. These conditions are species-specific. The most stenobiotic species is the pond myotis, and the species least demanding towards the hibernaculum conditions is the Daubenton's myotis. In addition, large hibernacula of pond myotis were found in Tanechkina Cave of the group of Staroladozhskije Caves; Natterer's myotis in Levoberezhnaya Cave of the group of Sablinskije Caves; Brandt's/whiskered myotis in Telezskije Caves; Daubenton's myotis in Tanechkina Cave and a few small caves, namely Korpovskaya, Rebrovskije, Borshchevskije. The number of pond myotis counted at the hibernacula ranged between 1600 and 1800 individuals, and quite accurately portrays the size of the region- 
al population; Daubenton's myotis counts at hibernacula account for around $10 \%$ of the regional population that estimates as 4000-4500 animals; the number of Natterer's myotis at hibernacula approximately correspond to their total regional population abundance that is less than 1000 individuals; the Brandt's/whiskered myotis is apparently somewhat more abundant in the region than what was maximally recorded from caves, since not all bat-inhabited underground structures are accessible, and the species population in the region is about 1000 animals; most of them do not hibernate in caves, and their total abundance is unknown, but appears to be very low.

Hibernating pond myotis are vulnerable because they massively concentrate only in one known cave (99\% in Tanechkina Cave). The most vulnerable species in the region are the Brandt's myotis and the Natterer's myotis because of low abundance and aggregation in several risk-exposed caves. The whiskered myotis in the region is vulnerable because of low abundance. The Daubenton's myotis is in the most secure situation.

ACKNOWLEDGEMENTS. The author is grateful to all those who have taken part in collecting data on bat hibernacula in different years: M.G. Noskova, I.Yu. Popov, N.N. Irashin, E.A. Shchekhovsky, A.D. Loginov, E.V. Palenova.

\section{References}

Airapetyants A.E., Strelkov P.P. \& Fokin I.M. 1987. [Animals]. Leningrad: Lenizdat. 143 p. [in Russian]

Bogdarina S.V. 2003. [The distribution of Chiroptera in the north of European Russia] // Plecotus et al. No.6. P.7-28 [in Russian].

Chistyakov D.V. 1999. [An assessment of the present-day condition of chiropteran (Chiroptera, Vespertilionidae) hibernacula in the Leningrad Region] // [Vestnik of SaintPetersburg University]. Series 3, Biology. Iss.1. No.3. P.41-47 [in Russian].

Chistyakov D.V. 2004. [Chiropteran hibernacula in underground (chiefly fortification) structures in the Leningrad Region] // Ilyjinskii I.V. (ed.) Trudy Biologicheskogo Nauchno-Issledovatelskogo Instituta SPbGU. Saint Petersburg: Izdatel'stvo Sankt-Peterburgskogo Gosudarstvennogo Universiteta. Vol.48. P.172-174 [in Russian].

Chistyakov D.V. 2009. [New data on chiropteran hibernacula in man-made underground structures in the Leningrad Region] // Plecotus et al. No.11-12. P.14-17 [in Russian].

Chistyakov D.V. \& Nikulin A.D. 2010. [Influence of anthropogenic factors on the condition of bats wintering of the Leningrad region] // Gunko A.A. et al. (eds.) Proceedings of the International Scientific and Practical Conference "Speleology and spelestologiya: development and interaction of Sciences". Naberezhnye Chelny: NGPI. P.320-322 [in Russian].

Ilyin V.Yu. \& Smirnov D.G. 2000. [Specific features of distribution of resident bat species (Chiroptera: Vesper- tilionidae) in the Eastern East European Plain and adjacent regions] // [Russian Journal of Ecology]. Vol.31. No.2. P.101-107 [in Russian].

Ilyin V.Yu., Smirnov D.G. \& Yanyaeva N.M. 2003. [The effect of anthropogenic factor on bats (Chiroptera: Vespertilionidae) of Volga Region] // [Russian Journal of Ecology]. No.2. P.134-139 [in Russian].

Khazanovich K.K. 1982. [Geological monuments of the Leningrad Region: sketch-guide]. Leningrad: Lenizdat. 78 p. [in Russian]

Khritankov A.M. \& Ovodov N.D. 2001. [On the longevity of Brandt's bats (Myotis brandtii Eversmann) in Central Siberia] // Plecotus et al. No.4. P.20-24 [in Russian].

Kovalyov D.N. 2011. [The problem of conserving the habitats of the pond bat - a rare bat species in St. Petersburg] // Vlasov D.Yu. (ed.) [Proceedings of the Ecological School in Peterhof - naukograd science city of the Russian Federation: "Environmental problems of urban areas in Northwest Russia and their potential solution"]. St. Petersburg: VVM. P.21-24 [in Russian].

Kovalyov D.N. 2012. [Gulf of Finland coasts as key habitats of the pond bat in the region] // Antsulevich A.E. (ed.) [Our common Gulf of Finland. Proceedings of the $1^{\text {st }}$ St. Petersburg University conference devoted to the Gulf of Finland Year 2014]. St. Petersburg: VVM. P.101-105 [in Russian].

Kovalyov D.N., Noskov G.A., Noskova M.G., Popov I.Yu. \& Rymkevich T.A. 2012. [The concept of building regional protected area networks (example of St. Petersburg and Leningrad Region). Part I. Ecological aspects] / / Biosphere. Vol.4. No.4. P.427-462 [in Russian].

Kovalyov D.N. \& Popov I.Yu. 2011. [Annual cycle of the pond bat (Myotis dasycneme) spatial distribution and abundance in Saint-Petersburg and Leningrad Region] // Transactions of the Karelian Research Centre RAS. Biogeography Series. Iss.11. No.1. P.68-82 [in Russian].

Kovalyov D.N. \& Schehovsky E.A. 2014. [Preliminary estimate of number of Daubenton's bat, Myotis daubentonii of the Leningrad region and St. Petersburg according to summer registrations] // Vlasov D.Yu. (ed.) Proceedings of the IX International ecological School conference in the manor "Sergiyevka" - a monument of natural and cultural heritage: "Preservation of environment and optimization of her use in the Baltic region". St. Petersburg: VVM. P.236-241 [in Russian].

Kovalev D.N., Popov I.Y. \& Schehovsky E.A. 2014. [The differences in species composition of bats on the wintering of Leningrad region, depending on the location and microclimate of underground shelters] // Vlasov D.Yu. (ed.) Proceedings of the IX International ecological School conference in the manor "Sergiyevka" - a monument of natural and cultural heritage: "Preservation of environment and optimization of her use in the Baltic region”. St. Petersburg: VVM. P.230-235 [in Russian].

Kozhurina E.I. 1997. [The bats of the European part of the former USSR. Field guide by exterior appearance]. Available from: http://sablino.narod.ru/library/bats.htm (accessed 19 April 2017) [in Russian]

Kozhurina E.I. 2009. [Synopsis of Russian bats fauna: taxonomy and distribution] // Plecotus et al. No.11-12. P.71-105 [in Russian]. 
Kuzyakin A.P. 1950. [Bats]. Moskva: Izdatel'stvo Sovetskaya Nauka. 443 p. [in Russian]

Limpens H.J.G.A., Lina P.H.C. \& Hutson A.M. 1999. A European action plan for the pond bat (Myotis dasycneme): a challenge // Cruz M. \& Kozakiewicz K. (eds.). European Bat Research Symposium: "Bats \& man: million years of existence". Kraków: Chiropterological Information Center Insitute of Animal Systematics and Evolution PAS. P.38-39.

Limpens H.J.G.A., Lina P.H.C. \& Hutson A.M. 2000. Action plan for the conservation of the pond bat in Europe (Myotis dasycneme) // Convention on the conservation of European wildlife and natural habitat (Nature and Environment. N.108). Strasbourg: Council of Europe Publishing. 50 p.

Masing M. 1990. Caves of Estonia - unique places of masshibernation of bats. Tartu: Estonian Academy of Sciences, Estonian Naturalists' Society. 82 p. [in Russian]

Mitchell-Jones A.J., Bihari Z., Masing M. \& Rodrigues L. 2007. Protecting and managing underground sites for bats. (EUROBATS Publication Series No. 2). Available from: http://www.eurobats.org/sites/default/files/documents/publications/publication_series/pubseries_no2 russian_2011.pdf (accessed 19 April 2017) [in Russian]

Orlov O.L. 1998. [Study of changes in the abundance of pond bats at the hibernaculum in Smolinskaya cave] // [Topical Problems of Biology]. Syktyvkar. P.134-135 [in Russian].

Orlov O.L. 1999. [Hibernacula of bats (Chiroptera, Vespertilionidae) in caves of the Sverdlovsk Region and their protection] // Contemporary Problems of Ecology, Microbiology, and Immunology. Perm. P.50-51 [in Russian].

Siivonen Y. \& Wermundsen T. 2003. First records of Myotis dasycneme and Pipistrellus pipistrellus in Finland // Vespertilio. Vol.7. P.177-179.
Smirnov D.G., Vekhnik V.P., Kurmaeva N.M. \& Shepelev A.A. 2012. [Seasonal features of the formation of the spatial structure of the population of bats in the dungeons of Samara Luka] // Povolzhskii Ekologicheskii Zhurnal. No.1. P.73-82 [in Russian].

Smirnov D.G., Vekhnik V.P., Kurmaeva N.M., Shepelev A.A. \& Ilyin V.Yu. 2008. Spatial structure of the community of Chiroptera: Vespertilionidae, hibernating in artificial galleries of Samara Luka // Izvestiya Rossiiskoi Akademii Nauk. Seriya Biologicheskaya. No.2. P.243252 [in Russian, with English summary].

Strelkov P.P. 1958. [Data on bat hibernacula in the European part of the USSR] // Trudy Zoologicheskogo Instituta AN SSSR. Vol.25. P.255-303 [in Russian].

Strelkov P.P. 1970. [Sedentary and migratory bat (Chiroptera) species in the European part of the USSR. Report 1] // Byulleten Moskovskogo Obshchestva Ispytatelei Prirody. Otdelenie Biologicheskoe. Vol.75. No.2. P.38-52 [in Russian].

Strelkov P.P. 1971a. [Ecological observations of hibernation in bats (Chiroptera, Vespertilionidae) in the Leningrad Region] // Trudy Zoologicheskogo Instituta AN SSSR. Vol.48. P.251-303 [in Russian].

Strelkov P.P. 1971b. [Sedentary and migratory bat species in the European part of the USSR. Report 2] // Byulleten Moskovskogo Obshchestva Ispytatelei Prirody. Otdelenie Biologicheskoe. Vol.76. No.5. P.5-19 [in Russian].

Strelkov P.P. \& Buntova E.G. 1982. [The whiskered bat (Myotis mystacinus) and Brandt's bat (Myotis brandti) in the USSR, and relationships between these species. Report 1] // Zoologicheskii Zhurnal. Vol.61. No.8. P.12271242 [in Russian].

Wermundsen T. 2010. Bat habitat requirements - implications for land use planning. Dissertationes Forestales 111. 49 p. Available from: http://www.metla.fi/dissertationes/df111.htm (accessed 19 April 2017).

\section{Appendix. List of internet-sources used for searching of caves and grottoes within territory of the Leningrad Region.}

Web-resource "NATUREworld", http://natureworld.ru;

Web-page of the Russian Society of Spelestological Research "Spelestology", http://rosi-spelesto.narod.ru;

Web-resource "Underground Speleological Portal of the Sablinskije Caves", http://sablino.narod.ru;

Web-resource "caves.ru", http://www.caves.ru. 